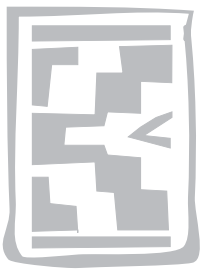

\title{
Striped mice, Rhabdomys pumilio, and other murid rodents as hosts for immature ixodid ticks in the Eastern Cape Province
}

\author{
T.N. PETNEY ${ }^{1}$, I.G. HORAK ${ }^{2 \star}$, D.J. HOWELL ${ }^{3}$ and S. MEYER ${ }^{2 \star *}$
}

\begin{abstract}
PETNEY, T.N., HORAK, I.G., HOWELL, D.J. \& MEYER, S. 2004. Striped mice, Rhabdomys pumilio, and other murid rodents as hosts for immature ixodid ticks in the Eastern Cape Province. Onderstepoort Journal of Veterinary Research, 71:313-318

Striped mice, Rhabdomys pumilio, were trapped over a period of 17 months in the Thomas Baines Nature Reserve, and placed in cages, over water, until all the ticks they harboured had detached. The mice were then returned to the reserve. Four ixodid tick species were recovered from the mice of which the larvae and nymphs of Rhipicephalus follis and Rhipicephalus simus were the most numerous. Most larvae of $R$. follis detached from mice trapped from March to July, and most nymphs in March and from June to September. Most larvae of $R$. simus detached from mice trapped from December to March, and most nymphs from January to March and during May and June. Seven ixodid tick species were collected from striped mice, house rats, Rattus rattus, vlei rats, Otomys spp. and Praomys sp. captured in the vicinity of human dwellings or animal holding facilities in the Grahamstown district. The striped mice captured in the Thomas Baines Reserve harboured considerably larger numbers of ticks than any of the rodent species in the more urbanized localities.
\end{abstract}

Keywords: Eastern Cape Province, ixodid ticks, Rhabdomys pumilio, Rhipicephalus follis, Rhipicephalus simus, rodents, seasonality, striped mice

\section{INTRODUCTION}

Several surveys on the ixodid ticks infesting a variety of rodent species have been conducted in South

* Author to whom correspondence is to be directed

** Present address: University of Pretoria Biomedical Research Centre, Faculty of Veterinary Science, University of Pretoria, Onderstepoort, 0110 South Africa

1 Tick Research Unit, Rhodes, Unversity, Grahamstown, 6140 South Africa. Present address: School of Pharmaceutical, Molecular and Biomedical Sciences, University of South Australia, GPO Box 2471, Adelaide SA 5001, Australia

2 Department of Veterinary Tropical Diseases, Faculty of Veterinary Science, University of Pretoria, Private Bag X04, Onderstepoort, 0110 South Africa. E-mail: ivan.horak@up.ac.za

3 Department of Agriculture and Water Supply, Uitenhage, 6320 South Africa

Accepted for publication 30 April 2004-Editor
Africa (Rechav 1982; Horak, Sheppey, Knight \& Beuthin 1986; Howell, Petney \& Horak 1989; Horak, Fourie, Novellie \& Williams 1991; Fourie, Horak \& Van Den Heever 1992; Braack, Horak, Jordaan, Segerman \& Louw 1996; Horak \& Boomker 1998; Horak \& Cohen 2001). Some of these rodents are significant, if not preferred, hosts of the immature stages of several tick species of which the adults are important parasites of domestic animals (Norval \& Mason 1981; Rechav 1982; Norval 1984; Braack et al. 1996). Despite their small size, the potential of rodents for rapid population growth and for maintaining high population levels can contribute significantly to the dynamics of tick species that use them as hosts (Norval 1979; Horak, Spickett \& Braack 2000).

In order to assess the significance of tick/rodent host relationships in the epidemiology of tick-borne 
diseases in South Africa, it is essential to know which tick species infest which rodent species and what levels the intensity of infestation can reach. In a previous paper (Howell et al. 1989), we suggested that striped mice, Rhabdomys pumilio, were of no significance in the epidemiology of heartwater, caused by Ehrlichia ruminantium, in domestic ruminants, because they did not represent significant hosts for the immature stages of Amblyomma hebraeum, the principal vector of this organism. In this contribution we wish to present data on other tick species that infested the same striped mice, and on the tick burdens of striped mice and other murid rodents in more urbanized habitats.

\section{MATERIALS AND METHODS}

The methods employed to collect ticks from the striped mice captured in the Thomas Baines Nature

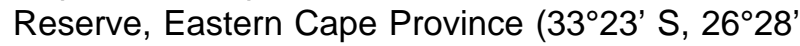
$\mathrm{E})$ have been described in detail by Howell et al. (1989) and will be repeated only briefly here. Except during September 1987, when no mice were trapped, striped mice were trapped each month from July 1987 to November 1988. These mice were kept in cages over water and once all their ticks had detached the mice were released in the vicinity of the sites at which they had been trapped. The ticks were collected from the water, dried and allowed to moult. When moulting was judged to be complete all the ticks that had moulted and those that had failed to moult were identified and counted. The counts of those that had moulted were converted to the previous life stage and added to those of the larvae or of the nymphs that had detached from the mice, but that had failed to moult.

Murid rodents were also trapped around the stables and dwellings at the field station of the Tick Research Unit, Rhodes University, around an animal shelter situated in a semi-rural environment close to the field station, and around the outbuildings and homestead of the small holding "Faraway", all within a 3 to $10 \mathrm{~km}$ radius of the centre of the city of Grahamstown (3319' S, 26³2' E), Eastern Cape Province. These rodents were killed and processed for the recovery of ticks as described by Horak et al. (1986).

\section{RESULTS AND DISCUSSION}

Four ixodid tick species were recovered from the mice trapped in the Thomas Baines Nature Reserve (Table 1). Of these the larvae and nymphs of Rhipicephalus follis and Rhipicephalus simus were the most numerous and the most prevalent. Four of the five $A$. hebraeum larvae and the single nymph recovered from the mice failed to moult to nymphs and to an adult respectively. Howell et al. (1989) have discussed the implications of this failure, coupled with the small number of ticks of this species collected from the mice, in relation to the epidemiology of heartwater, in detail. Twenty-four of the 36 larvae, and 11 of the 13 Haemaphysalis leachi nymphs recovered from the mice also failed to moult to the next life stage.

Most $R$. follis larvae detached from mice that were trapped from March to July, and most nymphs from those trapped in March and from June to September (Fig. 1). Of these 1806 larvae and 512 nymphs failed to moult.

Most larvae of $R$. simus detached from mice trapped from December to March, and most nymphs from those trapped from January to March and during May and June (Fig. 2). Of these 803 larvae and 172 nymphs did not moult.

The larvae and nymphs of $R$. follis and $R$. simus are very similar in appearance (Walker, Keirans \& Horak 2000) and although we attempted to separate them, it was particularly difficult to do so for the engorged larvae and nymphs that had died before moulting. Accordingly we cannot vouch for the absolute accu-

TABLE 1 Ixodid ticks in 172 collections from striped mice in the Thomas Baines Nature Reserve

\begin{tabular}{|l|r|r|r|r|}
\hline \multirow{2}{*}{ Tick species } & \multicolumn{2}{|l|}{ Number of ticks recovered } & \multirow{2}{*}{$\begin{array}{l}\text { No. of } \\
\text { collections }\end{array}$} \\
\cline { 2 - 5 } & \multicolumn{1}{|l|}{ Larvae } & Nymphs & \multicolumn{1}{|l|}{ Total } & 6 \\
\hline Amblyomma hebraeum & 5 & 1 & 6 & 18 \\
Haemaphysalis leachi & 36 & 13 & 49 & 162 \\
Rhipicephalus follis & 13313 & 704 & 14017 & 116 \\
Rhipicephalus simus & 2206 & 321 & 2527 & 169 \\
\hline Total & 15560 & 1039 & 16599 & 169 \\
\hline
\end{tabular}




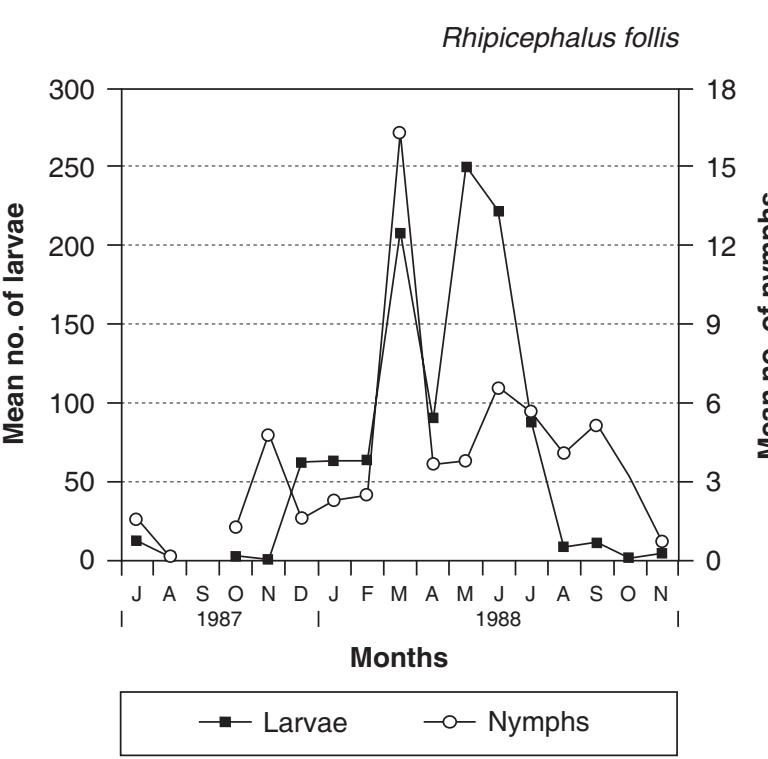

FIG. 1 The seasonal occurrence of the immature stages of Rhipicephalus follis on striped mice in the Thomas Baines Nature Reserve, Eastern Cape Province

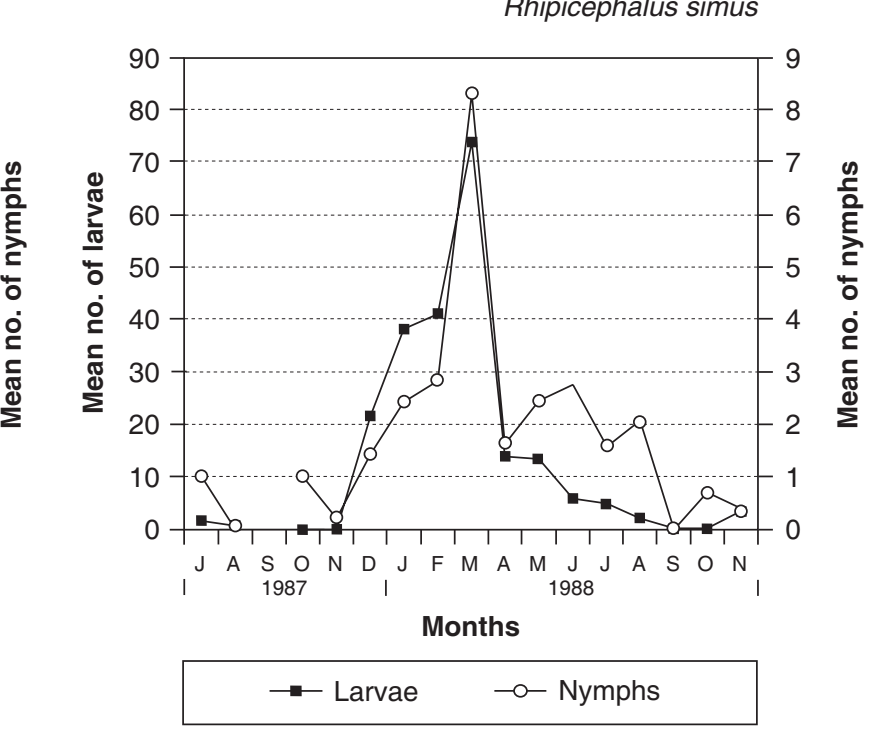

FIG. 2 The seasonal occurrence of the immature stages of Rhipicephalus simus on striped mice in the Thomas Baines Nature Reserve, Eastern Cape Province

TABLE 2 Ixodid ticks collected from 14 Rhabdomys pumilio in the Grahamstown district

\begin{tabular}{|l|l|l|l|l|}
\hline \multirow{2}{*}{ Tick species } & \multicolumn{2}{l|}{ Total number of ticks } & \multirow{2}{*}{ No. of rodents } \\
\cline { 2 - 5 } & Larvae & Nymphs & Total & \multirow{2}{*}{ infested } \\
\hline Haemaphysalis leachi & 42 & 11 & 53 & 6 \\
Ixodes sp. & 6 & 0 & 6 & 3 \\
Rhipicephalus (Boophilus) sp. & 1 & 0 & 1 & 1 \\
Rhipicephalus follis & 13 & 3 & 16 & 3 \\
Rhipicephalus simus & 37 & 0 & 37 & 6 \\
Rhipicephalus simus group & 8 & 0 & 8 & 1 \\
\hline Total & 107 & 14 & 121 & 10 \\
\hline
\end{tabular}

racy of the numbers that we have recorded for these species.

Ten of the 14 R. pumilio examined in the Grahamstown district were infested with ticks, and five species, of which $H$. leachi and $R$. simus were the most numerous and prevalent, were recovered from them (Table 2). Forty of the 73 Otomys spp., five of the 14 Praomys sp., and five of the 13 Rattus rattus examined in the Grahamstown district were infested and a total of six species were recovered, of which $H$. leachi was amongst the most numerous and prevalent (Tables 3-5).

\section{General}

The importance of the availability of rodents for the immature stages of tick species preferring these small mammals as hosts, on the subsequent num- bers of adults of the particular species, has been alluded to by Norval (1979) and demonstrated by Horak et al. (2000). The latter authors recorded a marked increase in the numbers of adult $R$. simus and Rhipicephalus turanicus, both of which use rodents as preferred hosts for their immature stages, on the vegetation of a landscape zone in the Kruger National Park approximately 8 months after a rodent explosion. On the other hand, no such increase in the numbers of adult Rhipicephalus appendiculatus, of which the immature stages feed on antelopes or hares, was noted.

The most striking differences between the tick burdens of the mice in the reserve and those of the rodents around human structures in the present study were the intensity of infestation and its prevalence and the species composition of the tick populations. The mean burdens of the various rodent 
Striped mice as hosts for immature ixodid ticks in Eastern Cape Province

TABLE 3 Ticks collected from 73 Otomys spp. in the Gahamstown district

\begin{tabular}{|l|c|l|l|r|r|}
\hline \multirow{2}{*}{ Tick species } & \multicolumn{2}{l|}{ Number of ticks recovered } & \multirow{2}{*}{$\begin{array}{l}\text { No. of rodents } \\
\text { infested }\end{array}$} \\
\cline { 2 - 6 } & Larvae & Nymphs & Females & Total & \\
\hline Amblyomma hebraeum & 1 & 0 & 0 & 1 & 1 \\
Haemaphysalis leachi & 48 & 9 & 0 & 57 & 15 \\
Ixodes alluaudi & 0 & 0 & 2 & 2 & 2 \\
Ixodes bakeri & 0 & 2 & 4 & 6 & 4 \\
Ixodes spp. & 11 & 0 & 0 & 11 & 6 \\
Rhipicephalus follis & 51 & 8 & 1 & 60 & 12 \\
Rhipicephalus simus & 33 & 18 & 0 & 51 & 18 \\
Rhipicephalus simus group & 4 & 27 & 0 & 31 & 3 \\
\hline Total & 148 & 64 & 6 & 218 & 40 \\
\hline
\end{tabular}

TABLE 4 Ticks collected from 14 Praomys sp. in the Gahamstown district

\begin{tabular}{|l|l|l|l|l|}
\hline \multirow{2}{*}{ Tick species } & \multicolumn{2}{l|}{ Total number of ticks } & \multirow{2}{*}{$\begin{array}{l}\text { No. of rodents } \\
\text { infested }\end{array}$} \\
\cline { 2 - 5 } & Larvae & Nymphs & Total & \\
\hline Amblyomma hebraeum & 0 & 1 & 1 & 1 \\
Haemaphysalis leachi & 10 & 0 & 10 & 3 \\
Ixodes bakeri & 0 & 1 & 1 & 1 \\
Ixodes sp. & 1 & 0 & 1 & 1 \\
\hline Total & 11 & 2 & 13 & 5 \\
\hline
\end{tabular}

TABLE 5 Ixodid ticks collected from 13 Rattus rattus in the Grahamstown district

\begin{tabular}{|l|l|l|l|l|}
\hline \multirow{2}{*}{ Tick species } & \multicolumn{2}{|l|}{ Total number of ticks } & \multirow{2}{*}{$\begin{array}{c}\text { No. of rodents } \\
\text { infested }\end{array}$} \\
\cline { 2 - 5 } & Larvae & Nymphs & Total & 5 \\
\hline Haemaphysalis leachi & 68 & 2 & 70 & 1 \\
Ixodes sp. & 1 & 0 & 1 & 1 \\
Rhipicephalus follis & 0 & 1 & 72 & 5 \\
\hline Total & 69 & 3 & & 1 \\
\hline
\end{tabular}

species examined close to Grahamstown varied between four ticks on infested Praomys sp. and 12 on infested $R$. pumilio, compared to 98 on infested mice in the Thomas Baines Reserve.

\section{Amblyomma hebraeum}

The significance of the six immature $A$. hebraeum recovered from the mice in the reserve compared to the abundance of these stages on the large bovids and the vegetation at the same locality has been discussed in an earlier publication (Howell et al. 1989). The single larva and nymph collected from the Otomys spp. and the Praomys sp. respectively examined in the Grahamstown district were not engorging and appeared to be dying, indicating an unsatisfactory host/parasite relationship, further emphasising the unsuitability of murid rodents as hosts for the immature stages of this tick.

\section{Haemaphysalis leachi}

The immature stages of $H$. leachi, of which the adults are specific parasites of domestic dogs and cats and the larger wild felids (Norval 1984; Horak Jacot Guillarmod, Moolman \& De Vos 1987; Horak, Braack, Fourie \& Walker 2000), were proportionally most numerous on the rodents examined close to Grahamstown. This is not surprising as workers at the field station and the owner of "Faraway" kept domestic dogs as pets, and dogs also accounted for a large proportion of the animals housed at the animal shelter. In a survey of the ticks infesting dogs on "Faraway" and on a neighbouring property con- 
ducted between August 1983 and July 1986, a total of 6146 adult $H$. leachi were collected and comprised $71.3 \%$ of all ticks recovered from the dogs (Horak et al. 1987). With this number of adult ticks on the dogs at "Faraway" higher burdens could have been expected on the rodents examined there. However, the immature stages do not feed exclusively on rodents, but also on dogs (Horak et al. 1987; Jacobs, Fourie \& Horak 2004), and this could be a reason for the smaller burdens. The $H$. leachi recovered from the striped mice in the reserve were probably the progeny of adult ticks feeding on wild carnivores there.

\section{Ixodes spp.}

All stages of development of Ixodes alluaudi and Ixodes bakeri infest shrews and rodents, with the latter tick showing a preference for Otomys spp. (Walker 1991). The unidentified Ixodes larvae collected from some of the rodents probably belonged to one or both of these species.

\section{Rhipicephalus (Boophilus) sp.}

The single larva collected from a striped mouse at the field station near Grahamstown is a "straggler" originating from ticks on cattle kept on the premises.

\section{Rhipicephalus follis}

Eland, Taurotragus oryx, examined in the Thomas Baines Nature Reserve during 1982 and 1984, and an African buffalo, Syncerus caffer, examined during 1985 harboured adult $R$. follis. It is the ticks on these hosts, and probably also on Burchell's zebras, Equus burchelli, in the reserve, which gave rise to the large numbers of immature ticks recovered from the striped mice at this locality.

Large numbers of adult $R$. follis have also been recorded on eland in the Mountain Zebra National Park near Cradock in the Eastern Cape Province (Horak et al. 1991) and the greatest intensity of infestation appeared to occur from August to March. Superimposing the seasonality of these adult ticks on that of the large number of larvae detaching from mice trapped in the Thomas Baines Nature Reserve from March to July, and of nymphs detaching during March and from June to September (Fig. 1) indicates that this three-host tick probably only completes one life cycle annually.

The immature stages of $R$. follis collected from the rodents examined close to Grahamstown probably originated from adults infesting cattle at the field station, horses at the animal shelter and dogs on "Faraway". Horses are also good hosts of $R$. follis, which at the time was identified as Rhipicephalus sp. (near R. capensis) (Horak, Knight \& De Vos 1986), as was the single adult tick on a dog at "Faraway" (Horak et al. 1987).

\section{Rhipicephalus simus}

Adult ticks on the eland, African buffaloes, zebras and carnivores in the reserve were the most likely source of immature $R$. simus on the striped mice at this locality, and on dogs, horses and cattle the source of the immature stages on the rodents examined in the vicinity of Grahamstown. In an earlier survey a total of 1351 adult $R$. simus was collected from dogs on "Faraway" and on a neighbouring property, and these ticks were most numerous from August to April (Horak et al. 1987). Superimposing this pattern of seasonality on that determined for the immature stages on the striped mice in the Thomas Baines Reserve indicates that this tick also only completes one life cycle annually, with most adults present during spring and summer, most larvae from mid to late summer, and most nymphs in late summer, autumn and winter. A similar survey conducted on striped mice in the Andries Vosloo Kudu Reserve, approximately $30 \mathrm{~km}$ north-east of Grahamstown, yielded most $R$. simus larvae from March to June and nymphs from June to September (Rechav 1982). Unfortunately Rechav (1982) did not state whether or not he collected the immature stages of other tick species from the mice.

\section{ACKNOWLEDGEMENTS}

The Cape Department of Nature Conservation and in particular Mr Brad Fike are thanked for their support during the study in the Thomas Baines Nature Reserve. Dr Amy Jacot Guillarmod of "Faraway" and Dr Jenny Randles of the animal shelter gave us permission to collect rodents at these localities. $\mathrm{Mr}$ Eddy Williams assisted with the collection of ticks from the rodents examined close to Grahamstown. This research was supported by financial grants from the Department of Agriculture and from the Foundation for Research Development (now the National Research Foundation).

\section{REFERENCES}

BRAACK, L.E.O., HORAK, I.G., JORDAAN, LEONORA C., SEGERMAN, JOYCE \& LOUW, J.P. 1996. The comparative host status of red veld rats (Aethomys chrysophilus) and bushveld gerbils (Tatera leucogaster) for epifaunal arthro- 
pods in the southern Kruger National Park, South Africa. Onderstepoort Journal of Veterinary Research, 63:149-158.

FOURIE, L.J., HORAK, I.G. \& VAN DEN HEEVER, J.J. 1992 The relative host status of rock elephant shrews ElephantuIus myurus and Namaqua rock mice Aethomys namaquensis for economically important ticks. South African Journal of Zoology, 27:108-114.

HORAK, I.G., POTGIETER, F.T., WALKER, JANE B., DE VOS, V. \& BOOMKER, J. 1983. The ixodid tick burdens of various large ruminant species in South African nature reserves. Onderstepoort Journal of Veterinary Research, 50:221-228.

HORAK, I.G., KNIGHT, M.M. \& DE VOS, V. 1986. Parasites of domestic and wild animals in South Africa. XX. Arthropod parasites of the Cape mountain zebra (Equus zebra zebra). Onderstepoort Journal of Veterinary Research, 53:127-132.

HORAK, I.G., SHEPPEY, K., KNIGHT, M.M. \& BEUTHIN, C.L. 1986. Parasites of domestic and wild animals in South Africa. XXI. Arthropod parasites of vaal ribbok, bontebok and scrub hares in the western Cape Province. Onderstepoort Journal of Veterinary Research, 53:187-197.

HORAK, I.G., JACOT GUILLARMOD, AMY, MOOLMAN, L.C. \& DE VOS, V. 1987. Parasites of domestic and wild animals in South Africa. XXII. Ixodid ticks on domestic dogs and on wild carnivores. Onderstepoort Journal of Veterinary Research, 54:573-580.

HORAK, I.G., FOURIE, L.J., NOVELLIE, P.A. \& WILLIAMS, E.J. 1991. Parasites of domestic and wild animals in South Africa. XXVI. The mosaic of ixodid tick infestations on birds and mammals in the Mountain Zebra National Park. Onderstepoort Journal of Veterinary Research, 58:125-136.

HORAK, I.G. \& BOOMKER, J. 1998. Parasites of domestic and wild animals in South Africa. XXXV. Ixodid ticks and bot fly larvae in the Bontebok National Park. Onderstepoort Journal of Veterinary Research, 65:205-211.

HORAK, I.G., BRAACK, L.E.O., FOURIE, L.J. \& WALKER, JANE B. 2000. Parasites of domestic and wild animals in South Africa. XXXVIII. Ixodid ticks collected from 23 wild carnivore species. Onderstepoort Journal of Veterinary Research, 67:239-250.
HORAK, I.G., SPICKETT, A.M. \& BRAACK, L.E.O. 2000. Fluctuations in the abundance of Boophilus decoloratus and three Rhipicephalus species on vegetation during eleven consecutive years. Proceedings of the Third International Conference on Ticks and Tick-borne Pathogens: into the $21^{\text {st }}$ Century. Institute of Zoology, Slovak Academy of Sciences, Bratislava, Slovakia, edited by M. Kazimírová, M. Labuda \& P.A. Nuttall: 247-251.

HORAK, I.G. \& COHEN, MARLENE. 2001. Hosts of the immature stages of the rhinoceros tick, Dermacentor rhinocerinus (Acari, Ixodidae). Onderstepoort Journal of Veterinary Research: 68, 75-77.

HOWELL, D.J., PETNEY, T.N. \& HORAK, I.G. 1989. The host status of the striped mouse, Rhabdomys pumilio, in relation to the tick vectors of heartwater in South Africa. Onderstepoort Journal of Veterinary Research, 56:289-291.

JACOBS, P.A.H., FOURIE, L.J. \& HORAK, I.G. 2004. A laboratory comparison of the life cycles of the dog ticks Haemaphysalis leachi and Rhipicephalus sanguineus. Onderstepoort Journal of Veterinary Research, 71:15-28.

NORVAL, R.A.I. 1979. The limiting effect of host availability for the immature stages on population growth in economically important ixodid ticks. Journal of Parasitology, 62:285-287.

NORVAL, R.A.I. \& MASON, C.A. 1981. The ticks of Zimbabwe. II. The life cycle, distribution and hosts of Rhipicephalus simus, Koch 1844. Zimbabwe Veterinary Journal, 12:2-9.

NORVAL, R.A.I. 1984. The ticks of Zimbabwe. IX. Haemaphysalis leachi and Haemaphysalis spinulosa. Zimbabwe Veterinary Journal, 15:9-17.

RECHAV, Y. 1982. Dynamics of tick populations (Acari: Ixodidae) in the eastern Cape Province of South Africa. Journal of Medical Entomology, 19:679-700.

WALKER, JANE B. 1991. A review of the ixodid ticks (Acari, Ixodidae) occurring in southern Africa. Onderstepoort Journal of Veterinary Research, 58:81-105.

WALKER, JANE B., KEIRANS, J.E. \& HORAK, I.G. 2000. The genus Rhipicephalus (Acari, Ixodidae): a guide to the brown ticks of the world. Cambridge: Cambridge Academic Press. 